\title{
Music from the Forest: on 'culture' among the Xokleng ${ }^{1}$
}

\author{
Kaio Domingues Hoffmann \\ PPGAS-UFSC
}

Among the Xokleng, a southern Ge group located in the state of Santa Catarina (Southern Brazil), the expression forest music designates songs that form part of the inventory of things obtained from the forest. Stories, mythic figures, food, musical instruments, clothing and medicine are just some of the other items encompassed by this topological (and temporal) qualification.

The time of the forest refers to the period prior to leaving the forest, an event that can be read in two ways. The first approach is to interpret the departure as a historical event: on the $22^{\text {nd }}$ of September 1914, Eduardo de Lima e Silva Hoerhan, an officer from the Indian Protection Service (SPI), ${ }^{2}$ made peaceful contact with the population known at the time as the 'Botocudos.' This marked the start of the policy of confining the group in villages, a process still known today as 'pacification.' ${ }^{3}$ It should be noted that before this intervention took place, European colonization (especially German) in the upper region of the Itajaí Valley had been threatened by the presence of indigenous groups, and extermination expeditions had even been organized, carried out by bugreiros - 'the bugres hunters.'4

1 This article is based on some of the ideas developed in my MA dissertation presented to the Postgraduate Program in Social Anthropology at the Federal University of Santa Catarina (Hoffmann 2011). I am grateful to my tutor Rafael José de Menezes Bastos, as well as my teachers Márnio Teixeira Pinto, Oscar Calavia Sáez, Marcela Coelho de Souza, Gabriel Coutinho Barbosa and Evelyn Schuler Zea, for their criticisms and suggestions during the qualifying exam for my research project and during my dissertation defence. I should also like to thank my colleagues from the Latin American and Caribbean Art, Culture and Society Laboratory (MUSA). The ideas explored in the article are, of course, entirely my own responsibility.

2 An institution disbanded during the 1970s, the precursor of the present-day National Indian Foundation (FUNAI).

3 Although at the time the regional population claimed to have pacified the indigenous people, and the latter claimed to have pacified the regionals (whom they called zug [whites/enemies]) (Ribeiro 1996), today the most commonly accepted version among the Amerindian and national population alike coincides with the first claim.

4 'Bugre' is a pejorative term commonly used in Southern Brazil. For further reading on 
Based on this information, it is common practice in the literature on the Xokleng to divide their history into pre and post 'pacification' periods with adjectives like traditional and autochthonous being associated with the former, and change and modernity, arising from contact with white people, being associated with the latter. ${ }^{5}$ This is the first approach to interpreting leaving the forest.

The other way points to the mythic relevance of the event. Here leaving the forest marks a rupture: it is from this point on that the native socius starts to acquire its contemporary form, creating a specific alterity between the forest Indians and the Indians from outside (the forest). Generally speaking, the narratives construct forest time (also known as the time of the ancient ones) as a period when the indigenous people had no fixed village, walked naked in the forest hunting, gathering honey and pine seeds, attacking and killing the whites, and held festivals with drink, music and dance. A time when they also communicated with the spirits (guardians) of animals and other beings of the cosmos.

According to the native discourse, therefore, transformation began with leaving the forest. Thereafter a process of differentiation unfolds, sometimes seen as a gradual loss in which dietary habits, beliefs and customs are transfigured. It is in this cosmological space that the Xokleng appear to situate themselves: the forest Indians are others. In this condition of extremely present pasts, these others help to constitute a thinkable political unit: "we, the outside Indians, the ones who left the forest." 6

Loch (2004) appears to have been the first author to explicitly formulate the significance of the forest in the native system of thought. Although the

'pacification,' see Coelho dos Santos (1973).

5 See, for example, Coelho dos Santos (1973), Urban (1978) and Wiik (2004). For a brief review of the anthropological literature on the Xokleng, see Hoffmann (2010).

6 Note that these questions as a whole evoke the discussion between myth and history. Though I have no intention of tackling this topic here, it is worth pointing out that the work of Lévi-Strauss $(1978,1990,1993 a, 1998$ and 2008) already suggests a dialogue between the categories, conceptualizing the transition from one to the other. Inspired by his ideas, more recent texts have reintroduced history into myth - see, for example, Calavia Sáez (2008), Goldman (1999) and Gow (2001). I would also observe that the mythic relevance for the Xokleng of the historical event of leaving the forest echoes what Menezes Bastos (2006) writes about the Kamayurá (Upper Xingu) for whom myth has an "originary and model nature, encapsulating prototypical catastrophes, or, precisely, origins. For the Kamayurá, then, if myth finds it calling in rupture, history by contrast finds its in continuity. It is as though for the Kamayurá the past - the past, the irrecoverably lost - only exists for myth, while for history only presents exist, more or less made present by the process of inquiry” (2006:570-1). 
opposition forest/outside Indians can be identified in earlier works, it is Loch who gives due importance to forest time as a time of inauguration. It is the fact of being inaugural and belonging to a certain prototypical past which makes a past event strongly present: "they are still (...) luminaries of this forest culture and seek to appropriate it in various ways - through dietary, medicinal and artistic customs" (2004:33).

It is here that the forest music appears to be situated: music associated with mythic time, evoking and actualizing this temporality whenever performed. It should be emphasized that this genre forms part of what I assume to be a native musical system. This system includes a tripartite division into forest music, evangelical hymns and real music (a genre defined in negative: everything that is neither forest music nor hymns). However, given the constraints of time and space, the present text will focus solely on the conceptions and expertise relating to forest music. ${ }^{7}$

Songs from the forest basically use two musical instruments: the voice and the rattle (txy). The latter consists of an oval calabash filled with seeds and pierced by a length of wood which the performer uses to hold the instrument. Sometimes the rattle is decorated with feathers. According to the system developed by Hornbostel and Sachs (1961), the rattle can be classified as an idiophone. ${ }^{8}$

During the performances I was able to watch, the rattle is always played in the same way, the forearm moved up and down at an angle a little over ninety degrees in relation to the arm. When lowered, the sound of the rattle is stronger and shorter, played in stacatto; when raised, the sound is less accentuated and more continuous. The resulting sound can be represented by two quavers, the marks on top of the first note indicating the accentuated and more interrupted (stacatto) dynamic compared to the second:

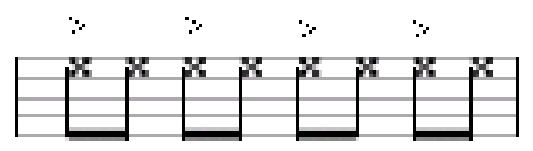

7 For a still incipient overview of this system, see Hoffmann 2011.

8 "Idiophones are instruments whose own ('idio') bodies contain the element responsible for generating its sound" (Menezes Bastos 2006: 573). 
The speed of the execution (tempo) seems to depend not only on the song, but also on the performer - the same song can be played in 110, 90 and 75 $\mathrm{bpm}$, for example. Generally the tempo of the songs that I heard varied between andante and moderato. The performer here is also a decisive factor: the slower tempos were all executed by the same person, the faster ones by another - suggesting that there was a speed at which each musician prefers to play. ${ }^{9}$

The rattle's timbre seems to be of considerable importance here and is commonly compared to other instruments: "it's like the guitar, it has to have the right tone." It must produce a strong/high and clear sound. During my field research one time, the lack of a rattle deemed good enough to play by musicians meant I was asked to wait for the following day so that they could play the music of the ancient ones the way it should be. Frequently many of the musicians also had no rattles at home and needed some time to obtain one (which would often be sold later to anyone interested). I deduce from this that without a rattle there is no song: there is no explicit hierarchy here labelling it as an 'accompaniment,' situating the rattle on a less important level than the song. Instead the rattle and voice work together to build a forest song - which, as I suggest further on, is intended to be like the songs which the Indians (from the forest) used to sing in mythic times.

As already noted by Henry (1964:200), the first anthropologist to study the Xokleng (during the 1930s), in many songs the voice is used primarily at one pitch. In the sample of songs I was able to collect, the notes vary, using the western scale, from $\mathrm{G} \# 3$ ( 415.30 hertz) to $\mathrm{E}_{4} 4$ ( 659.25 hertz), with the same song often performed in different notes (usually by different musicians). From this 'base note' are derived variations in syllables, duration and intensity, all occurring in conjunction with the sound emitted by the rattle. Other variations related to pitch may also occur, one of the most remarkable being a progressive and almost systematic micro-tonal rise in pitch as the song unfolds. In a song performed mainly in quavers and whole notes, for instance, this rise often appears to coincide with a longer note at the end of the strophe. Given the systematicity with which this rise occurs (in this and other songs), I would suggest that we cannot discard the phenomenon as an

9 This observation should be treated with some caution: since I did not always interact repeatedly with the same people, other factors of which I am currently unaware may influence song tempo. 
unimportant or insignificant feature..$^{10}$

The duration of the songs varies between approximately thirty seconds and three minutes. However these times are relative given that the song strophes can be repeated almost ad infinitum: everything appears to depend on a dialogue with the environment in which the performance is taking place. This fluidity in the finalization of the songs has also been observed among the Kaingang, another southern Ge group (Gibram 2008).

Another important resource in various songs is the whoop emitted at the end of the song, or less commonly in the middle - when the latter occurs, it apparently marks the end of a particular strophe. This 'heeey' is usually voiced at a higher pitch (from one to two tones) than the piece's base note (the most repeated note) and is usually executed in glissando - falling to a deeper indeterminate note.

In terms of the song lyrics, Henry (1964) had already noted that the words are articulated in a different way to verbal (spoken) language:

(...) Kaingáng [Xokleng] songs are completely made up of meaningless syllables. But their meaninglessness is of a peculiar character, for often the syllables themselves have meaning in an absolute sense; that is to say, they exist in the Kaingáng language as meaningful elements, though in the songs their arrangement and sequence is such that no meaning is derivable from them. It is as if we were to make a song in English of the syllables to, sigh, fly, me, and so on. There are words in our language which have the same phonetic structure as these syllables, but if I make up a song of these words alone, in the sequence given, it is obvious that they have meaning only if we insist on a very arbitrary definition of the word 'meaning.' (Henry 1964: 199, authors italics.)

Indeed the Xokleng today claim that the forest songs cannot be translated - even though some exegeses are based on words found in songs, connecting these words to stories from mythic time. It is important to bear in mind that the incomprehension generated by the lyrics - in both the musician and the audience and for different reasons (archaic, foreign lyrics etc.) - is not a rare and exotic phenomena but, on the contrary, extremely commonplace

10 According to Aytai $(1985: 17)$ this would also apply to Xavante music. On this raising of pitch, see too Seeger (1987) on the Suyá, Hill (1993) on the Wakuénai, and Menezes Bastos (1990) on the Kamayurá. For space reasons, these comparisons cannot be explored further here. 
(Menezes Bastos 1996)." If, as Ingold claims (2000), the difference between musical and verbal language is a difference of degree rather than kind, ${ }^{12}$ the question, I presume, is one of discovering the directions in which these songs point, looking and listening for the relations which they establish and which are established through them.

As I stated earlier, forest/ancient music, also called ãg djel, ${ }^{13}$ is strongly associated with the time of the forest and with everything described by this topological-temporal quality - of the forest. In a sense it is a music that activates (especially in rituals like National Indian Day) the mythic universe whose sore point is the great divide of leaving the forest. Like various other elements associated with this universe, it is heavily marked by a discourse of loss: "the music of the ancient ones no longer exists, the old people that knew it have all died", or "there are only one or two elderly people who still know" - these were some of the extremely common statements heard during my research (I return to this point later).

While the Xokleng claim to be the result of a metamorphic process begun by leaving the forest, no transfiguration is attributed to forest music. It is always described in terms of scarcity or extinction, whether in conversations with the anthropologist or among themselves, as though a certain irreducibility of the genre is involved, a refusal of change: nowadays no forest songs are composed. ${ }^{14}$ We could speak, perhaps, of a cold musicality, to enlist LéviStrauss's metaphor: a manner of perceiving the object (here, forest music) that valorizes the (illusion of) permanence (in this case, scarce, always endangered), the immutability relative to its time of creation.

Effectively it could be said that forest music has experienced and will

11 Note that among the Kamayurá of the Upper Xingu, "the relations between a song's music and lyrics are established under the condition that the latter 'goes into' the former, a formulation that indicates a relation by which lyrics are reducible to music" (Menezes Bastos 2002: 139).

12 “(...) in words, the process of sedimentation and compression of past usage which contributes to the determination of their current sense has advanced to an exceedingly high degree, whereas in melody it is still incipient. But this is a difference of degree rather than kind" (Ingold 2000: 409).

13 Ãg djél literally signifies 'our song.' I make more frequent use of the term 'forest music' and similar expressions due to the fact that my research was conducted almost entirely in Portuguese - although I strove to learn the language both formally and informally. I am aware of the advantages and disadvantages of this procedure (Viveiros de Castro 1999: 183-9). I emphasize that practically all the Xokleng are bilingual with a portion who are monolingual in Portuguese.

14 Henry (1964: 200) during the 1930s had a similar impression - that his informer knew a limited number of songs and that there were few new compositions. 
continue to experience transformations, reflected in the existence of variations on the same song. What the Xokleng emphasize, though, is the immutability of such songs: a kind of black box of the time of the forest, as though the forest music that nowadays only a 'few' (authorized) people know how to sing is the same music from mythic time. Interestingly enough, the native conception of musicality seems to be the symmetrical inverse of the prophetic quality attributed by Attali (1985) to music - instead of containing the core of what is still to come in social relationships, for the Xokleng it seems to indicate what has already passed at the level of relations in mythic time. ${ }^{15}$

Hence if this music is the mimesis of the time of origins, logically one cannot think of an intentional type of variation (composition) in this genre. It is a cold musicality whose efficiency is strongly connected to the reproduction of a previously posited form - an investment in reproduction rather than production, therefore (even if pragmatically reproduction consists of a kind of production/transformation with residues and refractions).

Returning to the discourse of loss and scarcity associated with forest music, I should emphasize that it can be nuanced by the Xokleng's own practice. Although the native diagnosis is usually mournful, suggesting its extinction, as I spent more time in the villages I discovered more and more people who knew these songs - and not just the elders. Despite the number having shrunk (when compared to the first decades of the $20^{\text {th }}$ century, when apparently everyone knew the songs now called forest music), the situation seemed quite different from what most of the discourses implied. ${ }^{16}$ What should we make of this discrepancy, then?

It is my impression that forest music was allocated a symbolic space that requires scarcity as a condition for its existence. It is important to note that forest knowledge is associated with the elders and that a society entirely made up of old people is inconceivable for the Xokleng. Additionally these characters, the elders, are not equated with 'traditional' knowledge in a mechanical way - none of them was born before the event of leaving the forest in $1914 .{ }^{17} \mathrm{At}$ the

15 In the Upper Xingu regional system, Menezes Bastos (2001) shows how various aspects of Kamayurá music also point to the past. Discussing the precursivity attributed to music by Attali (1985), Travassos (2007:196) observes that Blacking (1995:172) had published a similar idea the same year, arguing that music could anticipate changes in society.

16 For further information supporting the idea of extinction of the Xokleng music, see Hoffmann (2011).

17 In the case of the Xokleng, the mythic register does not seem to exclude a chronology. The same 
same time, they were the people who had the most contact with those who left: in this case, age and awareness of the things of the forest are directly proportional. Logically, then, today's children (usually accused of being uninterested) will be tomorrow's elders with this knowledge of forest things.

Perhaps a future longing might be more interesting to ponder than the retroactive desire projected by some ethnographies of the Xokleng: imagining whether a century from now forest music (and everything else associated with the forest) might not be embedded in a similar discourse. But futurology is not part of our job description, of course. I simply wish to point out that scarcity and the danger of extinction are constitutive elements of this domain.

This said, we need to determine where and when this music is present. It is not a frequent part of everyday life: one can spend months in a village and never hear it. However, the music is present on occasions such as the ceremonies held for National Indian Day and the like..$^{18}$ For a better understanding of the meanings activated by forest music, I therefore provide an analysis of a ceremony for National Indian Day among the Xokleng.

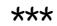

Sunday, April $19^{\text {th }}$ 2009. It was past midday and hot. Parked next to the road that traverses the indigenous territory was a truck, which would be used as a stage.

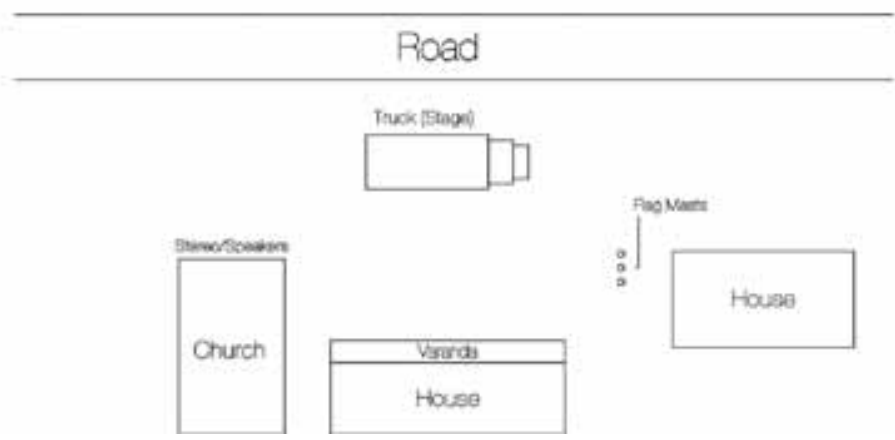

applies to the time of day: in addition to specifying the day and year, some versions of 'pacification' include the time of the encounters. This inclusion of hours to indicate time in the myths is also recorded by Vidal (2001:125-6 and 128) for the indigenous population of the Uaçá basin (Amapá state).

18 Other ceremonies include celebrations for 'pacification day' in September and the Inauguration Festival for the Tourism and Recreation Centre, which took place in 2003. See Langdon \& Wiik 2009 for a description of the latter. 
About four dozen people were gathered in a semi-circle in front of the truck, occupying the porch of the main house, the church and the area around the masts flying the flags of Brazil, Santa Catarina and the town of Vitor Meireles.

Wearing a shirt and trousers, clutching a piece of paper with a list of names in one hand and the microphone in the other, Jair, a young Xokleng man of about 25, calls the attention of those present in order to begin the ceremony. He talks about the important role of the event in assembling people from the village, emphasizing the pride of being Indian and the fight to ensure the Xokleng people do not come to an end. He also emphasizes the need to celebrate National Indian Day, which should be important not only for Indians but also for the 'outside authorities,' using this chance to add a criticism of the President of the Republic for decreeing the $19^{\text {th }}$ the "National Day of the Solder:' "unfortunately we have been forgotten by the authorities."

He apologises to those present for having been unable to prepare much in the way of entertainment. Nonetheless there would be a couple of presentations by students to "show that the Xokleng has not yet lost its customs, its culture." He then calls the Chief of Figueira Village, Enoque Popó, the president of the village council, Antonio Caxias Popó, and "our researcher, a law student who is doing her research here," Juliana, ${ }^{19}$ to raise the state, national and city flags respectively. He asks those people sitting to stand up as a mark of respect for the national anthem and the raising of the flags. As the anthem is played over the loudspeaker, the flags are raised - Brazil's flying higher than Santa Catarina's, which in turn is higher than Vítor Meireles's.

After the national anthem, Jair calls various local authorities to the improvised stage on the back of the truck: the chief and vice-chief of the village, the president of the local council, the preacher from the Evangelical church, and also the president chief, just as he was arriving. He also called the students/researchers, but stopped when he realized they were filming the event. The mayor of Vitor Meireles town had also been invited to the ceremony but failed to turn up. I mention this to show that there was no apparent intention to limit the speakers to members of the indigenous population when choosing the people to come on stage, much the opposite. However only

19 Juliana de Paula Batista, author of the dissertation Weaving law: Xokleng-Laklãnõ political organization and the construction of their own juridical systems - a contribution to legal anthropology (Batista 2010), at the time an MA student at the Federal University of Santa Catarina. 
authorities from the IT were standing on the back of the truck.

Next each of the people on stage makes more or less lengthy speeches, always in Portuguese, referring to the Xokleng present there as kin. Some begin with a religious greeting: "good morning to all, in the name of Jesus Christ the Lord." Many emphasized the importance of being together that day, rather than distant and apart. All the speakers refer to the problems and fights (for land and rights) in which the group is embroiled, mentioning the people's past and their future, including the hope for a better life - all accompanied by explicit declarations concerning the sadness and joy that the commemoration inspired. In the words of the president-chief Aniel: "Despite the discrimination we have experienced, we have resisted and we still exist. Why? Because we fought, we demanded our rights, we fought within white society for our rights, our customs, our culture, our tradition... to prove to this society that we exist."

Between each speech and sometimes even during them, the same music is played, issuing from the stereo player housed in the church, an instrumental song in which the sound of keyboard and flutes stood out sharply. I immediately recall the song 'El cóndor pasa,' played by the Peruvians selling their records in the main squares of Santa Catarina's capital. I ask the DJ what record he was playing. He replies with a vague comment about Indian music. ${ }^{20}$ The audience claps at the end of each speech.

Once the speeches are over, the preacher Daniel (who usually held services in the church) offers a sermon, citing passages from Christian mythology with their promises for the faithful. During the sermon, the word hallelujah produces a discursive cadence, a kind of a vignette, pronounced in the middle and at the end of sentences and periods. He then reads a Bible passage and concludes with a prayer. ${ }^{21}$

20 Playing this CD seemed to refer to some generic idea about Indianity - an idea which judging by this song seemed to dialogue with the Andean highlands rather than the South American lowlands. Beaudet (1997) had already noted that in the West, songs from the Andes (with their pan flutes) are much more famous than indigenous music from the South American lowlands, which in a way reinforces my impression that the Xokleng put into action an idea of generic Indianity via the song in question.

21 The prayers that I observed among the Xokleng (and which seem to be common to the Pentecostal universe) have no set text to be learned by heart or recited in unison by everyone - as other religious traditions require, such as Catholicism. The preacher (or the person responsible for leading worship) improvises the emotional phrases that make up the prayer, followed by numerous other phrases proclaimed by the followers, who may also say individual prayers - all of them speaking out loud, generating an interesting polyphony. 
The microphone is handed back to Jair who announces that the student presentations will start. The first is directed by Krendô, a teacher of indigenous art at the Laklãnõ school. Dressed like all the other adults present (shoes, smart shirt and trousers), Krendô has a rope covered with small feathers tied to his head. The rope drapes halfway down his back - an index of the forest time. The eighteen children, aged between five and ten, sit on their heels with their knees resting on the ground, facing each other in a line, ideally forming couples (although there were a few pairs of the same sex). At the front of the line, Krendô, who seems to be directing them. The boy belonging to the first couple seems to be one of the oldest and is the only one to hold a rattle. Over his pair of jeans he is wearing a straw skirt and his bare arms are covered two lines, which comprises his body painting. Some children are bare chested, wear the same straw skirts and carry small bows.

The DJ plays a cassette tape and the presentation begins. Everyone is silent, looking down at the ground, positioned close to the church. The sound comes from the speakers: it seems to be words in the native language, recited syllable by syllable by an elderly man. ${ }^{22}$ The children remain seated facing each other in a line. At the end of the taped recital, they stand up. Another voice is heard on the tape, ${ }^{23}$ asking the elderly man in Portuguese: "When did they sing this song? Was it a festival day?" Neither the reply nor the phrases that follow are audible - the tape has a lot of background noise. The pairs are now standing, in line, holding hands and facing forward. The elderly man on the tape starts singing and the children head to the centre of the semi-circle, forming a circle as they go. The boy at the front shakes his rattle in time with the song being played on the tape. And so the presentation proceeds with the sound of the song on the tape and the children holding hands walking in a circle, anti-clockwise, girls on the left of the boys (i.e. on the inner side of the circle). When the song finishes, the children stop, once again forming a line.

22 Everything suggests that the tape (and the presentation) comprises a representation of a discursive form translated by the Xokleng today as a desafio (challenge). Henry (1964:126) describes the game wainyêklâdn as follows: “(...) two men sit opposite each other and shout the myths at each other, syllable by syllable, very rapidly, while they swing their bodies back and forth to the rhythm of their shouting (...) The game of wainyêklâdn is played by two friends and serves no purpose other than that of drawing two people together. There are no stakes, and no goal is set. No one is downed, and no one triumphs." The tape appears to feature just a man, who seems to represent, for the person recording, how the challenge (game) was done.

23 This was Alexandro Namem, an anthropologist who studied the Xokleng from the end of the 1980s to the start of the 1990 . 
On top of the truck Jair announces that the presentation is over and asks for the audience's applause.

He then calls another presentation, this time to be performed by older students, aged from 14 to 16 . Five boys and girls, some with painted faces, stand in front of the stage holding sheets of paper. Each of them reads a passage of a poem about the importance of fighting in the present to ensure the future. At the end, applauses, quieter though.

Jair takes the microphone and says that before concluding, he would like to read a poem. 'Poem for a Xokleng Indian,' written by Lindolf Bell, a writer from Santa Catarina - a critical poem addressed to the white man, usurper of the Indian's wealth and beauty as well as his land. Jair then thanks everybody for being there and asks for applause in recognition of the day, April the $19^{\text {th }}$. The celebration of the National Indian Day thereby comes to an end in Figueira Village, followed by a barbecue freely distributed to everyone present. While people are eating, a woman from a neighbouring town asks to use the microphone and talks about her joy at being there. She sings an Evangelical hymn, accompanied by playback. Afterwards the sound system continues to play different hymns. People continue to chat and eat until some start to disperse, going back home.

So what is this ceremony about, in general? And more specifically, what role does forest music perform there?

The first aspect worth noting about the event is its formal mimesis of the civil ceremonies associated with the State: the stage, the speeches, the flags, the authorities and the national anthem. We can gain a better understanding of this organization by focusing our attention on the speeches, especially those parts referring directly to the Xokleng struggles and aimed at the State (and thus the world of the whites): the struggles to enlarge their lands, obtain compensation for the dam completed in the 1990s, and receive health services: in sum, the fight for better living conditions in their own terms.

The ceremony therefore seems to comprise a dialogue with the State within an asymmetric relationship: the latter is construed by the Xokleng as one of the main sources for their various misfortunes, while at the same being the only agent capable of alleviating the damage caused and "paying its debts" to them.

Thus we have a ritual form (a civil ceremony) mimetically appropriate for 
the ceremony of National Indian Day, which in turn focuses on the Xokleng struggles with the Brazilian State as one of its central themes. I suggest, therefore, that in a context where the indigenous people are explicitly seeking to 'call attention' (remembering the numerous invitations sent out to people from outside the village) there is an assumption that approximates the form of the 'text' to its content, generating a certain complicity between the terms. Holding a dialogue at ritual level assumes some degree of similarity and here it seems to me that the Xokleng theory of communication converges with Lévi-Strauss's (Lévi-Strauss 1993b). Following Rodrigues's interpretation of the latter,

(...) communication constitutes a complex game of similarities and differences, approximation and separations, convergences and divergences. Communion signifies the triumph of the Same, but communication is only possible as a dialectic of Alterities, that is, as something that happens at some point between a maximum distance and a maximum proximity. In a nutshell: excessive similarity, communication impossible; excessive difference, ditto. (Rodrigues 2009: 59).

Proceeding in a formal manner similar to the State festivities - and the National Indian Day instituted by the State, by 'white society,' as the Xokleng themselves affirm - seems to be a way of achieving effective action in a dispute where the sum of the results is never zero. ${ }^{24}$ It appears no coincidence that the songs played through the loudspeakers between the speeches evoked something like a 'generic Indianity' (see note 20) - it is worth recalling that the nation states were among the main inventors of this generic Indian identity. In order to produce a response in the latter, therefore, a type of song is played that evokes national stereotypes of the Amerindian world.

24 This formal mimesis is also typical of the political positions in the IT: elections are held and there are councils, a regional chief (and vice-chief) in each village and a chief-president (and vice-president) for the IT as a whole. "Now [in contrast to the time of the ancient ones, in the forest] it is just like a municipal government," Aniel (the chief president) emphasized. These terms are not translated into the native language, while there is a profusion of other terms typical to public and legal administrative systems, such as minutes, assemblies and so on - all of which, it seems to me, converge with a communicative potentialization with State agencies (recalling here that the main functions of the community leaders are to negotiate with these agencies, fighting to ensure their constitutional rights). "Since it is in a legally and administratively controlled environment that one learns how to be an Indian, an identity that, once fully assumed, allows them to become immersed in Brazilian society, understanding the ambiguous place which it reserves for them," writes Gallois (2005:113) in relation to the Wajãpi. 
Among the Cuna (Colombia and Panama), Taussig (1993) had already pointed to the importance of mimesis during the contacts with European colonizers - through figures sculpted in wood copying white characters and later the images taken from adverts. There Taussig emphasizes the magic of mimesis where the copy acquires the power of the original - a copy subject to sensory re-significations, of course. This is mimesis as a form of constructing power (the power to heal and destroy, in the Cuna case).

In addition to potentializing communication with the State through the mimesis of a ritual form (with the deployment of specific types of song, political positions and processes), it is important to note that the Xokleng are also exposing a dimension of the State that is often eclipsed: its pomp. In his study of the $19^{\text {th }}$ Century Balinese Theatre State, Geertz (1991) claims that the term 'state' has another two etymological dimensions beyond the meaning of governance/command (so emphasized by modern analysis). These are: status (in the sense of position) and pomp (in the sense of splendour, dignity). Since the emphasis in the Social Sciences typically fell on the idea of command, the other two meanings were seen as residual elements, superficialities or masks hiding and mystifying the 'real' interests. In constructing the model used to understand the negara, Geertz looks to show that the concept of power in this context reveals what our concept of power conceals, and vice versa (1991:153154). In other words, a kind of inversion. The author emphasizes the opposite, then: how governance serves pomp as the ultimate objective of the Balinese State, rather than the contrary. The government here is subordinate to festival and ceremony (which the governing power sees as the proper place for symbolic magnification and where mimesis is a crucial factor: "without the dramas of the theatre state, the image of composed divinity could not take form" [1991:165]).

Leaving Bali and returning to Santa Catarina, it is interesting that the mimesis of the state contexts made by the Xokleng emphasizes precisely their pomp (the civic ceremony appropriate for National Indian Day) and status (political positions), with the notion of governance becoming somewhat diluted. People occupying the position of chief (the president and the regional leaders) are not usually attributed the power to order (other residents of the IT). Instead they are responsible for 'outside' issues, in particular demands made to State agencies to ensure their constitutional rights are met. We can note, therefore, that the dimension of governance is not particularly 
emphasized in the native mimesis of State dimensions, which may be an important point in terms of re-thinking and re-working some of the ideas explored by Clastres (2003).

But when using mimesis on National Indian Day (and other occasions) as a device enabling communication with the State, the Xokleng also need to produce difference (already anticipated by the 'Andean' song), and indeed this seems to be one of the aims of the presentation: to show that since they are Indians and thus different, they possess specific rights that must be respected. The (semi)nudity, the straw, feathers, bows, paint, the dance circle, the rattle and the music of the forest activated and (re)created mythic time, the time of the forest. Perhaps we could treat them as indexes, echoing the semiotic approach of Peirce (1972): elements that establish a contiguity with the universe of which they are par, acting as indicative signs. Among the Xokleng, such elements constitute what they call 'culture' (closely linked, as I hope to have made clear, to this mythic time of the forest).

$\star * *$

All of this would seem to evoke the debate over the objectification of 'culture': in other words, the situation where it ('culture') ceases to be an exclusive part of anthropology's theoretical arsenal and enters the public domain (as has already been the case for some decades), especially when voiced by natives - our 'objects' (Sahlins 1997).

Turner (1991) compares two periods in Kayapo history: the time coinciding with his first fieldwork during the 1960 and the second with his return in the 1980s. According to the author, during this second period the Kayapo had developed a new form of social consciousness, more capable of offering political resistance to their 'contact situation,' something missing during the initial phase. In this new period, the Kayapo had become conscious of the political value of their 'culture,' in large part as a result of the different relationships developed with anthropologists, photographers, journalists, filmmakers, museum experts and so on, who, in contrast to missionaries and SPI agents, had no intention of promoting integration (whether economic or spiritual) but of learning and collecting. ${ }^{25}$ Turner goes on to analyze the

25 It is increasingly common nowadays, including among the Xokleng, to hear accusations like: "the anthropologist X was here and stole our culture - he learned from us, then left and wrote a book, earned money and never came back." This 'learning' and 'collecting' (of photos, artefacts, music) is perceived, therefore, as a kind of predation (Menezes Bastos 2007 and 2009). 
Kayapo use of audio-visual media in their political struggles, which shift from means of representation to ends in themselves - the event taking place in order to be recorded (rather than the recording being the documentation of an event that occurs for other reasons). ${ }^{26}$

However from an consciousness of the political value of 'culture,' Turner (1991) turns to perceiving this movement as a process of "cultural and ethical self-awareness," which to me appears to suggest a degree of contiguity between culture as an analytic and descriptive resource of anthropology and 'culture' as a political resource of the so-called traditional populations - as if there were a 'culture' prior to and outside of the political relations of which the Amerindians might or might not become aware. ${ }^{27}$

It is precisely this contiguity which other authors have questioned, looking to identify the constitution of this 'culture' in different contexts.

Weiner (1997 and 1999), for example, discussing the political clash between the Ngarrindjeri and the Australian State over the construction of a bridge, emphasizes that 'Aboriginal traditional culture' is a relational product in which the diverse actors (including anthropologists, the media, the State and the various Ngarrindjeri subgroups) form inextricable components. In other words, it is not a question here of a certain group becoming conscious and starting to use its 'culture' as a political resource, but rather the production of a notion of tradition based on specific relationships.

Weiner (1999:205) seems to assume, however, that this 'Aboriginal' relationality and cultural objectification are exclusive to contact with the 'West. ${ }^{28}$ Returning to Turner's text (1991: 304), we can note that he refers to a Kayapo concept, kukràdjà, designating a body of knowledge and customs, which has been used by the indigenous people in a similar way to the idea of

26 The same occurs today in relation to music in the indigenous societies of lowland South America: "following a global trend dating back to at least the 196os, the Indians themselves have become increasingly aware that the direction, control and management of the production and circulation of goods from the sphere commonly labelled 'Art \& Culture' (frequently capitalized) constitute a strategic and sensitive aspect of the political economy and ideology of the world system, encompassing its nation states and minorities like ethnic groups" (Menezes Bastos 2009:4-5).

27 Turner's constant references to the category of consciousness seem to be traceable back to the Marxist concept of ideology (Marx 1986).

28 I would also note that in one passage Weiner (1999:205) seems to over-simplify the various pre-contact traditional forms as if they were less relational than those of today. Turner (1991:294) also advances the idea of a relatively autonomous and self-sufficient social unit for the Kayapo prior to the 'contact situation.' 
'culture. ${ }^{29}$ What I wish to suggest here by citing this case is that even prior to contact with the white world the Kayapo probably already had a term to objectify what they now call 'culture' (though this does not mean that they imply the same thing). But it is not only there that objectification has been around for a long time. Harrison (2000) shows that pre-colonial societies in Melanesia had forms of objectifying cultural symbols, such as rituals, songs and myths, turning them into possessions. Hence objectification cannot be seen as a product of colonialism. What the colonial situation brought (and still brings) is another conception of property in relation to these goods: from negotiable prestige goods (some even made to be exchanged), they begin to be seen as legacies of the past (Harrison 2000:676).

Leaving aside the issue of the objectification of 'culture' as something not necessarily new, no one seems to disagree that objectifications observable over the last decades appear to present a different type of phenomenon, encompassing diverse subjects and institutions.

Setting out from the difference between culture in the form that emerges from anthropological practice and the 'culture' that emerges from the political clashes over identity, Coelho de Souza (2005) raises a number of questions for ethnographic consideration (how do the productions surrounding cultural heritage and intellectual property acquire meaning in different native contexts?), identifying tensions which the processes of turning 'culture' into 'heritage' can articulate (material/immaterial, singular/plural, identity/ alterity).

Already in the 1970s, Carneiro da Cunha (2009a) had raised the issue of 'culture' as a native category through the notion of ethnicity. For the author, ethnicity should not serve as an analytic category, which would not lessen its importance as a native category "used by social agents to whom it is relevant," comprising an "important form of eminently political protests" (2009a:244).

In a more recent text, Carneiro da Cunha (2009b) once again emphasizes the separation between the analytic and native domains,$^{30}$ this time

\footnotetext{
29 See also the discussion of the term presented by Coelho de Souza (2005).

30 I note that this is not a watertight separation but involves continually circulating categories that mutually (re)inform each other: "the analytical categories (...) produced in the centre and exported to the rest of the world also return today to haunt those who produced them: (...) they are things that come and go, diffracted and returned to the sender. Categories of ida y vuelta," in a beautiful analogy
} 
resorting to the use of quote marks: culture as a descriptive category of anthropology (which however polysemic and criticised it may be is extremely difficult to abandon) and 'culture' (in quote marks) as a resource deployed in an ethnic regime vis-à-vis Nation States. Their content does not differ but both belong to a different discursive universes, passing through re-translations at different levels.

But how can this discussion over appropriations of the word 'culture' help us to comprehend the commemoration of National Indian Day and the place of forest music (and other elements from the forest) among the Xokleng?

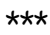

Langdon and Wiik (2009) provide a description of the Inauguration Festival for the Tourism and Recreation Centre, held in Figueira village in 2003. According to the authors, the aim of the festival was to emphasize and build 'Xokleng identity,' in a dialogue with both the national and international panorama of valorizing 'culture' and 'tradition. ${ }^{31}$ The organization of the festival was similar to that for National Indian Day, albeit with greater emphasis on the native language and on things from the forest. Presentations/ ritual performances (with dancing and sings) as well as games followed the speeches by the authorities present. The objective was to display 'culture,' aesthetically objectified in different forms to those elements also present in my description of the National Indian Day.

It is possible to think of the two ceremonies (the inauguration festival and the National Indian Day commemoration) as analogous: both used the time of the forest (music, dance and body decoration) to construct and insert the group in a prototype of Indianity, instigating a dialogue with the Brazilian State and the world of the whites. I would observe that through the use of this generic prototype of Indianity, the Xokleng are seeking both political and social effectiveness in relation to an agent (the State) that seems to establish the terms of its policies towards Amerindians through this generic Indianity(Menezes Bastos 1998a).

The two ceremonies also seem to present similar 'problems.' Langdon and Wiik (2009) noted unfinished elements in the festival, ranging from

\footnotetext{
with the cantes flamencos (Carneiro da Cunha 200gb:312).

31 Langdon and Wiik (2009) also seem to suggest a certain contiguity between native and analytic categories, here mainly revolving around 'identity.'
} 
the construction of the 'traditional' house to the non-realization of some of the planned activities, as well as the lamented number of people attending, considered low by the Xokleng - the festival was held solely at the initiative of Figueira Village: issues relating to internal factionalism prevented the involvement of the entire IT (Langdon \& Wiik 2009:182). I would also note that during my stay in the village I never once heard about the Tourism and Recreation Centre or other similar facilities (the Memoriam House, built near the school for a similar purpose but which also appeared to be in disuse). We can also recall that at the National Indian Day commemoration Jair apologised for the small number of presentations they had been able to prepare, most of which were performed by children (similar ceremonies in other villages also hold this kind of presentation). Performances involving adults and elders require greater effort, as happened at the inauguration festival in ${ }_{2003}{ }^{32}$ (and even there numerous 'lacunas' were evident).

What I wish to show is that despite the mythical force associated with the time of the forest, the Xokleng actions aimed towards this sphere are performed with a certain parsimony, or even incompleteness. At the same time that the things from mythic time are seen to be necessary for the construction of an indigenous collective in these ceremonies, the Xokleng appear to be have a certain fear or reluctance to appropriate and construct these indexes (an economy even). I think, therefore, that these 'lacunas' can be seen as something that indicates the relationship between the Xokleng and the things of the forest. 33

Perhaps an explanation for this parsimony in appropriating practices and objects from the forest (including music) can be found by recalling that the forest Indians are others. Others who formed the starting point for the

32 An elderly man once explained that adults rarely danced and sang during these presentations as many wanted to be paid for their participation - just like whites when playing music at dances: they charge a fee (the comparison is his own).

33 In other words my evaluation differs slightly from that of Langdon and Wiik (2009:181): "processes of re-traditionalization, 'displaying Xokleng culture,' the 'pure Indian,' are clearly on the rise, evinced by the organization of the Inauguration Festival for the Tourism and Recreation Centre, the culture house, the dance hall, bilingual education, and so on." I agree that these processes may be on the rise, but I stress that this increment seems to occur in a very specific key - that of scarcity. It is important to remember that the Xokleng do not form part of the trope of indigenous authenticity found in the national imaginary - a sad trope that creates a typicality and alienability that weighs on those very indigenous peoples occupying this imaginary (Viveiros de Castro 1979), one of its symptoms being the representation of the 'beautiful Indian' and the 'ugly Indian' (Menezes Bastos 1983: 45-6). 
successive transformations enabling the present-day human condition. It seems that from a native perspective, excessive investment in this mythic repertoire would carry the risk of a new transformation, this time in reverse, bringing them closer to the forest Indians - a catastrophic event that would invert the native 'sociogony, ${ }^{34}$ causing the Xokleng to leave their condition as civilized people (a term used by themselves which seems to refer to obtaining and domesticating the potency of the knowledge and objects associated with the whites). As elsewhere (Kelly 2005:212, Vilaça 2000:69), the series of transformations in this case does not appear to be reversible.

Discussing the National Indian Day celebrations among the Yanomami from Maturacá (AM), Smiljanic (2009) observes that the presentations involved in the ceremony performed rituals indicating the relationship between the Yanomami and their diverse others. By objectifying 'culture' and 'tradition' through these presentations, the Yanomami were expressing the complexity (and the danger arising from the predatory logic) of their status as 'civilized' people, subjects who had acquired the capacities of the whites as agents.

It seems to me that the National Indian Day ceremony among the Xokleng touches on similar aspects to those described by Smiljanic (2009), insofar as the Xokleng performances also show a relationship of alterity, but in this case in the representation of these others (from the forest) through the performances as well as through the differentiation of bodies (Seeger et. al. 1987) - in the body painting and nudity, but also in the ritual performances (dancing).

A deep investment in the representation of those others therefore seems to lead to a reverse transformation undesired by the Xokleng. In other words, they need the forest Indians in order to construct themselves as humans (Indians and konhká [family]). They extract something from these beings, and this something is what they conceive as 'culture,' presented and actualized during the National Indian Day celebrations and the like, ceremonies that instigate a dialogue with the world of the whites (the State and anthropologists included) - they extract a value from one of their others (forest Indians) in order to constitute themselves vis-à-vis another of their others (the whites). I would argue that if we remove the human/animal opposition and violence

34 With this word I refer to the genesis of full social and human condition for the Xokleng (the rupture marked by leaving the forest). 
from the notion of predation, conceiving it in a minimal form, we can think of this extraction (and momentary capture) of value (the elders' 'culture') as precisely this: a form of predation. However, doing this we would be removing a vital part of the concept: "one of the main characteristics of predation: the establishment (...) of a dichotomy between predator and prey, understood as an opposition between humans and animals" (Vilaça 1998: s. p.). Another concept of predation is developed by Fausto (2001), who understands it as a way of controlling other subjectivities - a productive process which aims to produce new subjects. His approach seems to emphasize the positional character more than Vilaça's (1998). Given the purpose of this article, I refrain here from deepening and developing the debate surrounding the category of predation - particularly since, in the Xokleng case, the data with which I am working seem to limit me to this point. I emphasize, therefore, for now, that it involves more an extraction and capture of value based on forest things, than a form of predation properly speaking, given that these others from the forest are also not contemporary to the Xokleng.

Finally, the Xokleng simultaneously refuse to invest too much in this extraction of things from the forest. This, I believe, is the key to understanding the discourse on extinction and scarcity concerning forest music: after all, as already mentioned, to start behaving and doing things like the elders (the forest Indians) would represent a reversal of their continuous process of transformation, whose initial, original point is the forest. They themselves would become the ones from the forest, making it conceptually impossible for them to extract 'culture' from these beings (now themselves): to share an identity makes predation unfeasible (Vilaça 1998 and 2000) - and here we can recall that in the Amerindian world culture is something that always comes from outside (Carneiro da Cunha 2009b). The capture of 'culture' from the things from the forest (and the perspective inscribed in people's bodies as a result of this capture) must therefore be necessarily momentarily and ritually marked.

Nonetheless the relationship between the forest and outside the forest locates the Xokleng in a position of exteriority. It is not, therefore, an extraction from the outside - neither can the forest be equated with any kind of interiority since the Xokleng were the ones who left it. The opposition seems to be more strongly associated with a diachronic level than a synchronic/ topological level, with the forest, mythic time, being equated with anteriority. I do not think we can understand this anteriority to possess any kind of 
interiority, essence or nucleus. It does not involve, I believe, any form of topological extraction (neither exterior nor interior) and the type of extraction implied is momentary and parsimonious due to the dangers of a reversal in the process of transformation - it involves a certain kind of domestication of the potency of things from the forest through their minimal and economic appropriation. ${ }^{35}$

Between the specular and complementary model of the construction of the person that operates through the pairing of opposites - "I am that which what I am not is not" (Carneiro da Cunha 1978:145) - and the supplementary model of incorporating predation which takes the other as destiny (Viveiros de Castro 1986), the relationship of the Xokleng with this other from the forest seems to approximate the former, though with a slight inflection, since the Xokleng opposition embodies a diachrony which also turns to the past: that which I am not is inserted in the past tense, and my reflection in relation to it acknowledges a continuity that operates through transformations that differentiate me from it: at the same time that it provides me with a contrasting image (we, the outside Indians, who wear clothes, live in brick houses, know Jesus, and so on), this image also comprises the origin of the present condition of our socius- an image not only of an opposite quality, but also of a preceding one.

Finally, in constructing 'culture,' the Xokleng turn to their mythic repertoire in a very specific way, where a parsimonious extraction of this past other (now made present) is needed to enable their continuous transformations (which takes this other as a starting point, never as an end). All of this seems to constitute the place indicated by the native rhetoric of 'acculturation,' which seems to differ substantially from the homonymous anthropological notion.

Music, since it is always present on these occasions of putting myth (the time of origins and ruptures) into action, is an important element of this overall process. It amounts to one more item in the repertoire of the native

35 The term 'domestication' may not be the most appropriate here given that it can imply the neutralization and assimilation of dangers connected to the exterior and to enemies (Van Velthem 200o). I suggest that in the Xokleng case it is more a question of precaution. A continuous and exaggerated appropriation of indices from the forest would cause a reversal in the Xokleng transformation, causing them to lose their present human condition - it is like leaving the things from the forest in a cage, as rather than domesticating them to bring them 'inside.' 
mythic universe - pondered and appropriated through the notion of scarcity. The way in which music is approached and lived by the Xokleng seems to indicate a model of relationship implicating other artistic modes linked to the forest time - as well as a political use.

In this text, therefore, I have tried to identify a set of factors within which forest music is simultaneously inserted and assists in their construction. However, though I have insufficient data at present to elucidate its specific role in this process, we should not lose sight of the fact that whatever music does/says, it does/says in a specific way (just like the spoken, dance, graphic designs and so on), each channel possessing its own communicative specificity (Menezes Bastos 2001 and 2007). Although I have not tried to tackle this task in full here, I believe that the first step has been taken, meaning that we can already make out something like a figure - to use the kind of visual analogy favoured by Western sensibilities (and modes of cognition: Menezes Bastos 1998b) - towards which forest music converges: mythic time, politics and 'culture' (with all of its parsimony and production of forgetting) as important and constitutive dimensions of this universe.

\section{Bibliography}

ATTALI, Jacques. 1985. Noise: the political economy of music. Manchester: Manchester University Press.

AYTAI, Desidério. 1985. O mundo sonoro xavante. São Paulo: Universidade de São Paulo, [Coleção do Museu Paulista, Etnologia, vol. 5].

BATISTA, Juliana de Paula. 2010. Tecendo o direito: a organização política dos Xokleng-Laklãnõ e a construção de sistemas jurídicos próprios - uma contribuição para a antropologia jurídica. MA dissertation in Law, PPGD/ UFSC - Florianópolis.

BEAUDET, Jean-Michel. 1997. Souffles d'Amazonie: les orchestres "Tule" des Wayãpi. Nanterre: Société d' Ethnologie (Collection de la Société Française d' Ethnomusicologie, III).

BLACKING, John. 1995. "The study of musical change”. In: Music, culture and experience: selected papers of John Blacking. Chicago and London: The University of Chicago Press.

CALAVIA SÁEZ, Oscar. 2008. "A história pictográfica". In: Caixeta de Queiroz, R.; Nobre, R. F. (eds.). Lévi-Strauss: Leituras brasileiras. Belo Horizonte: 
Ed. UFMG. pp. 125-146.

CARNEIRO DA CUNHA, Manuela. 1978. Os mortos e os outros: uma análise do sistema funerário e da noção de pessoa entre os índios Krahô. São Paulo: Hucitec.

CARNEIRO DA CUNHA, Manuela. 2009a. "Etnicidade: da cultura residual mas irredutível” [1979]. In: Cultura com aspas. São Paulo: Cosac Naify. pp. 235244.

CARNEIRO DA CUNHA, Manuela. 2009b. ““Cultura” e cultura: conhecimentos tradicionais e direitos intelectuais”. In: Cultura com aspas. São Paulo: Cosac Naify. pp. 311-374.

CLASTRES, Pierre. 2003. A sociedade contra o Estado. São Paulo: Cosac Naify.

COELHO DE SOUZA, Marcela Stockler. 2005. "As propriedades da cultura no Brasil Central indígena”. Revista do Patrimônio Histórico e Artístico Nacional, 31: 316-335.

COELHO DOS SANTOS, Silvio. 1973. Brancos e índios no sul do Brasil: a dramática experiência dos Xokleng. Florianópolis: Edeme.

FAUSTO, Carlos. 2001. Inimigos fiéis: história, guerra e xamanismo na Amazônia. São Paulo: Editora da USP.

GALlOIS, Dominique Tilkin. 2005. "Os Wajãpi em frente da sua cultura”. Revista do Patrimônio Histórico e Artístico Nacional, 31: 111-129.

GIBRAM, Paola Andrade. 2008. Kagma Ti Eg Kã Ki: um estudo panorâmico sobre a música dos índios Kaingang da T.I. Xapecó. Trabalho de Conclusão de Curso do curso de Ciências Sociais, UFSC - Florianópolis.

GOLDMAN, Marcio. 1999. "Lévi-Strauss e os sentidos da história”. Revista de Antropologia, 42(1-2): 223-238.

GOW, Peter. 2001. An amazonian myth and its history. Oxford: Oxford University Press.

HARRISON, Simon. 2000. "From prestige goods to legacies: property and the objetification of culture in Melanesia". Comparative Studies in Society and History, 20: 662-679.

HENRY, Jules. 1964. Jungle people: a Kaingang tribe of the highland of Brazil. New York: Vintage Books.

HILL, Jonathan D. 1993. Keepers of the sacred chants: the poetic of ritual power in an amazonian society. Tucson and London: The University of Arizona Press.

HOFFMANN, Kaio Domingues. 2010. "De alguns pressupostos analíticos na 
literatura sobre os Xokleng: esboço para uma breve revisão bibliográfica". Espaço Ameríndio, 4: 233-248.

HOFF MANN, Kaio Domingues. 2011. Música, mito e parentesco: uma etnografia xokleng. Dissertação de Mestrado em Antropologia, PPGAS/UFSC Florianópolis.

HORNBOSTEL, Erich M.; Sachs, Curt. 1961. "Classification of musical instruments" (translated from the original german by Anthony Baines and Klaus P. Wachsmann). The Galpin Society Journal, 14: 3-29.

INGOLD, Tim. 2000. The perception of the environment: essays on livelihood, dwelling and skill. London and New York: Routledge.

KELLY, José Antonio. 2005. "Notas para uma teoria do "virar branco"”. Mana. Estudos de Antropologia Social, 11(1): 201-234.

LANGDON, Esther Jean; Wiik, Flavio B. 2009. "Festa de inauguração do Centro de Turismo e Lazer: uma análise da performance identitária dos Laklãnõ (Xokleng) de Santa Catarina”. Ilha. Revista de Antropologia, 10: 171-199.

LEACH, Edmund Ronald. 1996. Sistemas políticos da Alta Birmânia: um estudo da estrutura social kachin. São Paulo: Edusp.

LÉVI-STRAUSS, Claude. 1978. Mito e Significado. Lisboa: Edições 70.

LÉVI-STRAUSS, Claude. 1993a. “Como morrem os mitos”. In: Antropologia estrutural dois. Rio de Janeiro: Tempo Brasileiro. pp. 261-274.

LÉVI-STRAUSS, Claude. 1993b. “Raça e história”. In: Antropologia estrutural dois. Rio de Janeiro: Tempo Brasileiro. pp. 328-366.

LÉVI-STRAUSS, Claude. 1998. "Lévi-Strauss nos go: voltas as passado". Mana, Estudos de Antropologia Social, 4(2): 107-117.

LÉVI-STRAUSS, Claude. 2008. “A estrutura dos mitos”. In: Antropologia estrutural. São Paulo: Cosac Naify. pp. 221-248.

LÉVI-STRAUSS, Claude; ERIBON, Didier. 1990. De perto e de longe. Rio de Janeiro: Nova Fronteira.

LOCH, Silvia. 2004. Arquiteturas xoklengs contemporâneas: uma introdução à antropologia do espaço na Terra Indígena Ibirama. Dissertação de Mestrado em Antropologia, PPGAS/UFSC - Florianópolis.

MARX, Karl. 1986. A ideologia alemã. São Paulo: Ed. Hucitec.

MENEZES BASTOS, Rafael José de. 1983. "Sistemas políticos, de comunicação e de articulação social no Alto Xingu”. Anuário Antropológico, 81: 43-58.

MENEZES BASTOS, Rafael José de. 1990. A festa da jaguatirica: uma partitura crítica interpretativa. Tese de Doutorado em Antropologia, Universidade 
de São Paulo - São Paulo.

MENEZES BASTOS, Rafael José de. 1996. "A “Origem do Samba” como invenção do Brasil (Por que as canções têm música?)”. Revista Brasileira de Ciências Sociais, 31: 156-177.

MENEZES BASTOS, Rafael José de. 1998a. "Antropologia como crítica cultural e como crítica a esta: dois momentos extremos de exercício da ética antropológica (entre índios e ilhéus)”. In: I. B. Leite (ed.). Ética e estética na antropologia. Florianópolis: Programa de Pós-Graduação em Antropologia Social/UFSC. pp. 99-115.

MENEZES BASTOS, Rafael José de. 1998b. "Apùap world hearing: a note on the Kamayurá phono-auditory system and on the anthropological concept of culture". Antropologia em Primeira Mão, 32: 5-20.

MENEZES BASTOS, Rafael José de. 2001. "Ritual, história e política no Alto Xingu: observações a partir dos kamayurá e do estudo da festa da jaguatirica (Jawari)”. In: B. Franchetto \& M. Heckenberger (orgs.). Os povos do Alto Xingu. Rio de Janeiro: Editora UFRJ. pp. 335-357.

MENEZES BASTOS, Rafael José de. 2002. "A Festa da Jaguatirica: primeiro e sétimo cânticos, introdução, transcrição e comentários". Ilha. Revista de Antropologia, 4(2): 133-174.

MENEZES BASTOS, Rafael José de. 2006. "Leonardo, a flauta: uns sentimentos selvagens”. Revista de Antropologia, 49(2): 557-579.

MENEZES BASTOS, Rafael José de. 2007. "Música nas sociedades indígenas das terras baixas da América do sul: estado da arte”. Mana, Estudos de Antropologia Social, 13(2): 293-316.

MENEZES BASTOS, Rafael José de. 2009. Como o conhecimento etnomusicológico é produzido? Trabalho de campo, produção de conhecimento e a apropriação indígena da fonografia - o caso brasileiro hoje. Antropologia em Primeira Mão, 113: 1-9.

PEIRCE, Charles Sanders. 1973. Semiótica e filosofia. São Paulo: Ed. Cultrix. RIBEIRO, Darcy. 1996. Os índios e a civilização: a integração das populações indígenas no Brasil moderno. Petrópolis: Editora Vozes.

RODRIGUES, José Carlos. 2009. "Lévi-Strauss, teórico da comunicação". Revista Famecos, 39: 57-62.

SAHLINS, Marshall. 1997. "O "pessimismo sentimental” e a experiência etnográfica: por que o a cultura não é um objeto em via de extinção (parte I e II)". Mana, Estudos de Antropologia Social, 3(1): 41-73. 
SEEGER, Anthony. 1987. Why Suyá sing: a musical anthropology of an amazonian people. Cambridge: Cambridge University Press.

SEEGER, Anthony; DAMATTA, Roberto; VIVEIROS DE CASTRO, Eduardo. 1987. "A construção da pessoa nas sociedades indígenas brasileiras". In: J. P. Oliveira Filho (ed.). Sociedades indígenas e indigenismo no Brasil. Rio de Janeiro: UFRJ/Marco Zero. pp. 11-29.

SMILJANIC, Maria Inês. 2009. "A comemoração do dia do índio entre os Yanomami de Maturacá (AM)”. In: M. I. Smiljanic; J. Pimenta; S. G. Baines (eds.). Faces da indianidade. Curitiba: Nexo Design. pp. 155-165.

TAUSSIG, Michael. 1993. Mimesis and alterity: a particular history of the senses. New York/London: Routledge.

TRAVASSOS, Elizabeth. 2007. "John Blacking ou uma humanidade sonora e saudavelmente organizada”. Cadernos de Campo, 16: 191-200.

TURNER, Terence. 1991. "Representing, resisting, rethinking: historical transformations of kayapo culture and anthropological consciousness". In: Stocking, G.W. (ed.). Colonial situations: essays on the contextualization of ethnographic knowledge. Madison: University of Wiscosin Press. pp. 285-313.

URBAN, Greg. 1978. A model of shokleng social reality. Unpublished Ph.D. Dissertation (Anthropology), University of Chicago - Illinois.

VAN VELTHEM, Lucia Hussak. 2002. “"Feito por inimigos”: os brancos e seus bens nas representações Wayana do contato”. In: B. Albert \& A. Ramos (eds.). Pacificando o branco: cosmologias do contato no norte amazônico. São Paulo: Ed. UNESP/Imprensa Oficial do Estado. pp. 61-84.

VIDAL, Lux Boelitz. 2001. "Mito, história e cosmologia: as diferentes versões da guerra dos Palikur contra os Galibi entre os povos indígenas da Bacia do Uaçá, Oiapoque, Amapá”. Revista de Antropologia, 44(1): 117-147.

VILAÇA, Aparecida M. N. 1998. "Fazendo corpos: reflexões sobre morte e canibalismo entre os Wari' à luz do perspectivismo”. Revista de Antropologia, 41(1): 9-67.

VILAÇA, Aparecida M. N. 200o. “O que significa tornar-se outro? Xamanismo e contato interétnico na Amazônia”. Revista Brasileira de Ciências Sociais, 15(44): 56-72.

VIVEIROS DE CASTRO, Eduardo B. 1979. "Quanto custa ser a metáfora de si mesmo: os paradoxos da identidade xinguana”. Publicações Avulsas, 1, [Museu de Antropologia, Universidade Federal de Santa Catarina, 
Florianópolis].

VIVEIROS DE CASTRO, Eduardo B. 1986. Araweté: os deuses canibais. Rio de Janeiro: Jorge Zahar Ed.

VIVEIROS DE CASTRO, Eduardo B. 1999. "Etnologia brasileira”. In: S. Miceli (ed.). O que ler na ciência social brasileira. São Paulo: Ed. Sumaré, 2 a Ed. WEINER, James F. 1997. "Bad aboriginal' anthropology: a reply to Ron Brunton". Anthropology Today, 13(4): 5-8.

WEINER, James F. 1999. "Culture in a sealed envelope: the concealment of australian aboriginal heritage and tradition in the Hindmarsh Island Bridge Affair. The Journal of the Royal Anthropological Institute, 5(2): 193-210. WIIK, Flavio B. 2004. "O evangelho transformado: apropriações xokleng (Jê) do cristianismo pentecostal". In: R. M. Wright (ed.). Transformando os deuses: igrejas evangélicas, pentecostais e neopentecostais entre os povos indígenas no Brasil (vol. 2). Campinas: Ed. da Unicamp. pp. 141-168.

\section{About the author}

Kaio Domingues Hoffmann

(dh.kaio@gmail.com)

MA from the Postgraduate Programme in Social Anthropology of the Federal University of Santa Catarina

\section{Publications}

HOFFMAN, Kaio D. 2008. 'Entre o campeiro e o comercial: alguns apontamentos sobre a música gaúcha na região metropolitana de Florianópolis.' Mosaico Social - Revista do Curso de Graduação em Ciências Sociais (UFSC), v. 4, p. 21-39.

HOFFMAN, Kaio D. 2009. 'Notas preliminares sobre a música xokleng.' In VIII RAM - Reunião de Antropologia do Mercosul, Buenos Aires

HOFFMAN, Kaio D. 2010. 'De alguns pressupostos analíticos na literatura sobre os Xokleng: esboço para uma breve revisão bibliográfica.' Espaço Ameríndio (UFRGS), v. 4, p. 233-248. 